\title{
Chemical, physical and mineralogical attributes of the soils of the Sertanejo pediplain in the sisal-growing areas of the semiarid Bahia
}

\section{Atributos químicos, físicos e mineralógicos de solos do Pediplano Sertanejo cultivado com sisal no semiárido baiano}

\author{
José Augusto Amorim Silva do Sacramento ${ }^{1 *}$; Jorge Antonio Gonzaga Santos ${ }^{2}$; \\ Oldair Vinhas Costa ${ }^{2}$; Leo Jakson da Silva Moreira ${ }^{3}$; Alide Mitsue Watanabe \\ Cova'; Marcela Rebouças Bomfim²
}

\begin{abstract}
Information and available knowledge of the soils of the Sertanejo pediplain are relatively scarce and restricted to survey data. Researches about soil characterization and classification contributes to the knowledge of different soil orders within a region and allows information to be obtained systemically based on the physical, chemical, and mineralogical properties of the soil. This study aimed to evaluate the genesis of the Sertanejo pediplain soils, through the characterization of the chemical and mineralogical properties and classification of the soils of the sisal-growing region. Five soil profiles located in Araci, Retirolândia, St. Dominic, and Valente, cities located in the sisal-growing areas of the Bahia semiarid region, were studied, described morphologically, and analyzed for chemical $\left(\mathrm{pH} \mathrm{H}_{2} \mathrm{O}\right.$ and $\mathrm{KCl}, \mathrm{Ca}^{2+}$, $\mathrm{Mg}^{2+}, \mathrm{K}^{+}, \mathrm{Na}^{+}, \mathrm{Al}^{3+}, \mathrm{H}^{+}+\mathrm{Al}^{3+}, \mathrm{P}$, and TOC) and mineralogical attributes. Most evaluated soil classes were formed by lithological discontinuity of material. The main processes involved in the formation of such soil classes were: cumulization, accretion, and lessivage. The mineralogy of the clay fraction observed was complex and included a variety of minerals, with a predominance of kaolinite and bayerite. In addition, we also found goethite and illite in most of the studied profiles, both in the sediment, horizons $\mathrm{P} 1 \mathrm{C} 2$, and in the crystalline horizon $\mathrm{P} 1 \mathrm{Cr}, \mathrm{P} 2 \mathrm{Bi}, \mathrm{P} 32 \mathrm{Cr}$, and P5 Bi. The soils were classified up to the fourth category level, as Entisol Eutrophic Inceptisol (RRE), Alfisols Haplic typical Eutrophic (SXE), and Inceptisols Ta Eutrophic vertissólico (CXve).
\end{abstract}

Key words: Alfisols. Entisols. Inceptisols. Mineralogy.

\section{Resumo}

As informações e o conhecimento disponível sobre os solos presentes no Pediplano Sertanejo são relativamente escassas, restringindo-se a informações produzidas pelos levantamentos em nível exploratório ou de reconhecimento. Pesquisas pedológicas sobre caracterização, mineralogia e classificação de solos, contribuem para o conhecimento das diversas ordens de solo de uma região e permitem sistematizar informações sobre os atributos físicos, químicos e mineralógicos dos solos. Este estudo objetivou determinar as propriedades químicas e mineralógicas, bem como a classificação

Prof. Dr., Universidade Federal do Oeste do Pará, UFOPA, Santarém, PA, Brasil. E-mail: jassacramento@yahoo.com.br

2 Profs. Drs., Universidade Federal do Recôncavo da Bahia, UFRB, Centro de Ciências Agrárias, Ambientais e Biológicas CCAAB, Cruz das Almas, BA, Brasil. E-mail: gonzaga.jorgeas@gmail.com; oldairvinhas@gmail.com; reboucas.marcela@gmail.com

3 Prof. Dr., Universidade Federal Rural da Amazônia, UFRA, Parauapebas, PA, Brasil. E-mail: leopontocom2004@gmail.com

4 Pós-Doutorando, UFRB, Centro de Ciências Agrárias Ambientais e Biológicas CCAAB, Cruz das Almas, BA, Brasil. E-mail: alidewatanabe@yahoo.com.br

* Author for correspondence 
de solos do Pediplano Sertanejo, representativos da região sisaleira. Cinco perfis de solos localizados nos municípios de em Araci, Retirolândia, São Domingos e Valente pertencentes à região sisaleira, semiárido baiano, foram abertos, descritos morfologicamente e analisados nos seus atributos químicos ( $\mathrm{pH}$ em água e $\mathrm{KCl}, \mathrm{Ca}^{2+}, \mathrm{Mg}^{2+}, \mathrm{K}^{+}, \mathrm{Na}^{+}, \mathrm{Al}^{3+}, \mathrm{H}^{+}+\mathrm{Al}^{3+}, \mathrm{P}$ e C) e mineralógicos. A maioria das classes de solos avaliadas são formadas por descontinuidade litológica. Os principais processos envolvidos na formação das classes de solos foram: cumulização, agradação e lessivagem. A mineralogia da fração argila observada é complexa e composta de uma variedade de minerais, com predomínio da caulinita e bayerita. Além destes, também foram encontrados goethita e ilita na maioria dos perfis estudados, tanto no sedimento, nos horizontes P1 C2, como no cristalino, horizontes P1 Cr, P2 Bi, P3 2Cr e P5 Bi. Os solos foram classificados, até o quarto nível categórico, como: Neossolo Regolítico Eutrófico léptico (RRe); Planossolo Háplico Eutrófico típico (SXe) e Cambissolo Háplico Ta Eutrófico vertissólico (CXve).

Palavras-chave: Planossolos. Neossolos Regolíticos. Cambissolos. Mineralogia.

\section{Introduction}

Brazil is the world's largest producer and exporter of sisal fiber, which is the fiber produced by Agave sisalana (IBGE, 2013); therefore, its cultivation is of great economic and social importance, mainly because it is cultivated by small farming families in the northeastern region. The edaphoclimatic characteristics of the northeastern semi-arid region favor the production of this agavaceous species (BRANDÃO et al., 2013).

Information on soils on which sisal is cultivated, i.e., the representative soils of the Sertanejo pediplain, is relatively scarce, and is restricted to that obtained from exploratory surveys (OLIVEIRA et al., 2009). Studies on soil characterization, mineralogy, and classification contribute to the knowledge on the different orders of soil in a region, and allows systematic information to be obtained on the physical, chemical, and mineralogical attributes of the soils.

Soil surveys gather important information that allows soils to be used in rational and efficient ways, including for agricultural use. Information can also serve as a subsidy for the development of more sustainable management practices and can help producers to achieve greater agricultural productivity (SANTOS et al., 2012). Studies of this nature are particularly important in the semi-arid regions, especially in the sisal-growing region, given the social and economic importance associated with the cultivation of this crop.
The soils of the sisal-growing region are represented by approximately 90\% Planosols and 10\% Regolitic Neosols (BRASIL, 1983; MELO et al., 2001; EMBRAPA, 2006).

\section{Planosols ((Alfisols) (SOIL TAXONOMY,} 2014) are soils with a horizonal sequence of A-ABBt-Btn or A-E (albic or not) -Bt-Btn and a clayey texture at the subsurface horizon (SANTOS et al., 2013). Vertically, these are very differentiated soils, presenting a poor clay horizon covering another rich fraction of the same texture. Although most of the natural chemical conditions are reasonable to good, they substantially limit agricultural use owing to their physical conditions and their susceptibility to erosion and degradation (PARAHYBA et al., 2010). The characterization, mineralogy, and classification of these soils have not been elucidated, especially in terms of the study environment; furthermore, there is questionable understanding of the associations of these soils with the Regolithic Neosols ((Psamments and Orthents) SOIL TAXONOMY, 2014) (PARAHYBA et al., 2010).

The Neosols ((Entisols) (SOIL TAXONOMY, 2014) have A or hystic horizons, positioned directly on rock or on a $\mathrm{C}$ or $\mathrm{Cr}$ and $\mathrm{R}$ horizon, and vary in texture from sandy to medium (SANTOS et al., 2013). Generally, the scarcity of rainfall in the semiarid region, both isolated and region-wide, limits the intensity of pedogenetic processes (SANTOS et al., 2012). 
Thus, when considering the existence of soil classes different to those previously discussed, studies aim to morphologically, chemically, and mineralogically characterize the soils representative of the sisal-growing region, and subsequently classify them. Characterization and classification of these soils complements information from the exploratory surveys of soils existing in the sisalgrowing region, helping to provide more detailed information for the planning of occupation and land use in this region. Thus, this study aimed to evaluate the morphological, chemical, and mineralogical attributes, as well as the classification of soils of the Sertanejo pediplain, representative of the sisalgrowing region.

\section{Materials and Methods}

\section{Characterization and location of study areas}

Pits were dug in the areas of sisal cultivation, in the municipalities of Retirolândia, Araci, Valente, and São Domingos, belonging to the semi-arid regions of Bahia. Two pits were opened in Retirolândia (Profiles 1 and 2); one in Araci (Profile 3); one in Valente (Profile 4); and one in São Domingos (Profile 5). These profiles were named $\mathrm{P} 1, \mathrm{P} 2, \mathrm{P} 3, \mathrm{P} 4$, and $\mathrm{P} 5$ respectively. The pits were dug in the middle third of the slope, as this was the most representative part of the sisal-growing areas.

The climate of the sisal-growing region, according to the Koppen classification scheme, belongs to the BSh type (very hot semi-arid, with annual average rainfall between 500 and $800 \mathrm{~mm}$ ). November and December are the wettest months and the average annual temperature varies between 20.7 and $26.8^{\circ} \mathrm{C}$.

The geology of the region includes igneous and metamorphic rocks, with the metamorphic grades varying from granulite to shale-green, Archean and lower Proterozoic eon. The relief is gentle undulating, flattened, and ramped forms, with elevations varying from 240 to $400 \mathrm{~m}$, and residual elevations up to $300 \mathrm{~m}$, providing evidence of the intense denudation and planing processes to which the region has been subjected. The relief of the regions is peculiar, wih multiple pontoons and inselbergs, structured by granulite orthogneisses and granitoids, and residual reliefs in the form of crystals, where calcissilictic and quartzite rocks are formed (MELO et al., 2001).

The geomorphology is composed of interplanaltic depressions, a marginal hilly plateau, which is a flattened surface, inclined planes, uniform coverings of different origin, resulting from retouches and successive relocations, indicating predominance of areolar erosion processes (BRASIL, 1983).

The original dominant vegetation in the region was the open-tree caatinga (SEI, 2016), belonging to the caatinga biome. Some characteristics of the areas in which the profiles were excavated are presented in Table 1.

\section{Sample collection and analytical procedures}

The profiles were described according to Santos et al. (2015). Deformed soil samples collected from each horizon were air-dried and passed through sieves with a 2-mm diameter mesh. The coarse gravel fraction, with a diameter of $>2 \mathrm{~mm}$ and the air-dried fine ground. The samples were analyzed chemically for $\mathrm{pH}$ in water $\left(\mathrm{pH} \mathrm{H}_{2} \mathrm{O}\right)$ and $\mathrm{pH}-\mathrm{KCl}$, total soil organic carbon (C), $\mathrm{P}, \mathrm{K}^{+}, \mathrm{Na}^{+}, \mathrm{Ca}^{2+}, \mathrm{Mg}^{2+}$, $\mathrm{Al}^{3+}$, and $\mathrm{H}^{++} \mathrm{Al}^{3+}$, as described by Donagema et al. (2011). Based on the analysis, the cation exchange capacity (CEC), base sum (BS), base saturation (V), and aluminum saturation $(\mathrm{m})$ were determined.

The texture of the samples was analyzed using the densimeter method (DONAGEMA et al., 2011). Minerals were identified in natural clay without treatment. After the clay was separated by sedimentation, the particles were disintegrated by sieving and the fraction was gently ground with an agate mortar. The mineralogy of the total clay fraction $(\varnothing<2 \mu \mathrm{m})$ of the samples was 
determined using a radius diffractometer $\mathrm{X}$ (DRX) Pan Analytical - X'pert PRO model with a cobalt $\mathrm{X}$-ray tube, under a scanning velocity of $0.02^{\circ}(2 \theta)$, and analyzed in the range of 4 to $70^{\circ}(2 \theta)$. The minerals of the diffractograms were interpreted as described by Chen (1977). The total content of iron, aluminum, and silicon compounds in the TFSA fraction were evaluated in the acid of sulfuric attack (DONAGEMA et al., 2011). Based on the results, the soil weathering stage was evaluated using $\mathrm{Ki}$ and $\mathrm{Kr}$ indexes.

Table 1. General information on the characterization of soil profiles in the sisal-growing areas in the Bahian semi-arid region.

\begin{tabular}{|c|c|c|c|c|c|c|c|c|}
\hline Profile & $\begin{array}{l}\text { Coord. } \\
\text { (UTM) }\end{array}$ & $\begin{array}{c}\text { Landscape } \\
\text { situation }\end{array}$ & $\begin{array}{l}\text { Local } \\
\text { relief }\end{array}$ & $\begin{array}{l}\text { Source } \\
\text { material }\end{array}$ & $\begin{array}{c}\text { Current } \\
\text { vegetation }\end{array}$ & $\begin{array}{c}\text { Altitude } \\
\text { (m) }\end{array}$ & Drainage & $\begin{array}{l}\text { Pedregosity } \\
\text { and richness }\end{array}$ \\
\hline P1 & $\begin{array}{l}24 \mathrm{~L} \\
0459181 / \\
8726158\end{array}$ & $\begin{array}{l}\text { Middle } \\
\text { third }\end{array}$ & $\begin{array}{l}\text { Soft } \\
\text { wavy }\end{array}$ & $\begin{array}{l}\text { Sandy } \\
\text { sediment } \\
\text { covering the } \\
\text { lens }\end{array}$ & $\begin{array}{l}\text { Sisal } \\
\text { consortium } \\
\text { with native } \\
\text { pasture }\end{array}$ & 314 & $\begin{array}{l}\text { Excessively } \\
\text { drained }\end{array}$ & $\begin{array}{l}\text { Endoped, } \\
\text { absent }\end{array}$ \\
\hline P2 & $\begin{array}{l}24 \mathrm{~L} \\
0450560 / \\
8728466\end{array}$ & $\begin{array}{l}\text { Middle } \\
\text { third }\end{array}$ & $\begin{array}{l}\text { Soft } \\
\text { wavy }\end{array}$ & $\begin{array}{l}\text { Product of } \\
\text { alteration of } \\
\text { crystalline } \\
\text { granulite }\end{array}$ & Sisal & 269 & $\begin{array}{l}\text { Imperfectly } \\
\text { drained }\end{array}$ & $\begin{array}{l}\text { Slightly } \\
\text { stony and } \\
\text { slightly } \\
\text { rocky }\end{array}$ \\
\hline P3 & $\begin{array}{l}24 \mathrm{~L} \\
8751628 / \\
496730\end{array}$ & $\begin{array}{l}\text { Middle } \\
\text { third }\end{array}$ & $\begin{array}{l}\text { Soft } \\
\text { wavy }\end{array}$ & $\begin{array}{l}\text { Product of } \\
\text { alteration } \\
\text { of sandy } \\
\text { quaternary } \\
\text { sediments } \\
\text { covering the } \\
\text { lens }\end{array}$ & Sisal & 298 & $\begin{array}{l}\text { Imperfectly } \\
\text { drained }\end{array}$ & $\begin{array}{l}\text { Moderately } \\
\text { stony and } \\
\text { slightly } \\
\text { rocky }\end{array}$ \\
\hline P4 & $\begin{array}{l}24 \mathrm{~L} \\
0445227 / \\
8739022\end{array}$ & $\begin{array}{l}\text { Middle } \\
\text { third }\end{array}$ & $\begin{array}{l}\text { Soft } \\
\text { wavy }\end{array}$ & $\begin{array}{l}\text { Sandy } \\
\text { quaternary } \\
\text { sediment } \\
\text { change } \\
\text { product }\end{array}$ & Sisal & 315 & $\begin{array}{l}\text { Dramatically } \\
\text { drained }\end{array}$ & $\begin{array}{l}\text { Stony and } \\
\text { not rocky }\end{array}$ \\
\hline P5 & $\begin{array}{l}24 \mathrm{~L} \\
0439716 / \\
333306\end{array}$ & $\begin{array}{l}\text { end of } \\
\text { middle } \\
\text { third }\end{array}$ & $\begin{array}{l}\text { Soft } \\
\text { wavy }\end{array}$ & $\begin{array}{l}\text { Crystalline } \\
\text { rock } \\
\text { alteration } \\
\text { product }\end{array}$ & $\begin{array}{l}\text { Sisal with } \\
\text { dirty grass }\end{array}$ & 230 & $\begin{array}{l}\text { Moderately } \\
\text { drained }\end{array}$ & Absent \\
\hline
\end{tabular}

Based on their morphological, physical, chemical, and mineralogical attributes, soils were classified according to the Brazilian Soil Classification System - SiBCS (SANTOS et al., 2013).

\section{Results and Discussion}

\section{Morphological and physical attributes of soil}

The predominant coloration of $\mathrm{P} 1$ and $\mathrm{P} 4$ was dark brown and brown, respectively (Table 2).
These hues are characteristic of soils containing little organic matter and are consistent with the results reported by Santos et al. (2012), who characterized Regolithic Neosols in the semi-arid region of the Pernambuco sertão. Dark brown and very dark brown colorations predominate in the superficial horizons of $\mathrm{P} 2$ and $\mathrm{P} 5$, respectively, and reddish coloration predominates in the subsurface. In P3, grayish brown and dark grayish brown colors predominate. The reddish colors in the subsurface 
of P2 and P5 indicate the presence of iron, which originates from the crystalline material and gives rise to soil classes that differ from the Planosols and Regolithic Neosols, as indicated by the exploratory surveys in the sisal-growing region.

The Cr horizon lies at depths of 0.55 and 0.65 $\mathrm{m}$ in the $\mathrm{P} 2$ and $\mathrm{P} 3$, and at depths of 0.98 and 0.72 $\mathrm{m}$ in the P1 and P4 profiles, respectively. The depth difference of the $\mathrm{Cr}$ horizon in the evaluated profiles is related to the position of the profiles in the relief, and the texture, which is predominantly sandy. Thus, profiles that are at higher altitudes contain sand in all horizons, ranging from 77 to $83 \%$, such as profiles $\mathrm{P} 1$ and $\mathrm{P} 4$ (Table 2), and present a greater infiltration of water. The $2 \mathrm{Cr}$ horizon presents soil mass mixed with rock fragments, with a massive porous structure and olive gray color.

Table 2. Distribution of the horizons and morphological attributes of the sisal-growing soil in the semi-arid region.

\begin{tabular}{|c|c|c|c|c|c|c|c|c|}
\hline \multirow[t]{2}{*}{$\mathbf{P}$} & \multirow[t]{2}{*}{ Hz. } & \multirow{2}{*}{$\begin{array}{c}\text { Prof. } \\
(\mathrm{m})\end{array}$} & \multirow{2}{*}{$\begin{array}{l}\text { Color } \\
\text { Damp }\end{array}$} & \multirow[t]{2}{*}{ Structure } & \multicolumn{2}{|c|}{ Consistency } & \multirow{2}{*}{\multicolumn{2}{|c|}{$\begin{array}{l}\text { Transition } \\
\text { Wer }\end{array}$}} \\
\hline & & & & & Dry & Damp & & \\
\hline & \multicolumn{8}{|c|}{ Entisol Eutrophic Inceptisol - RRe } \\
\hline \multirow{7}{*}{ P1 } & A & $0-0,14$ & $\mathrm{BA}$ & bsa, me, fr e gs & $\begin{array}{c}\text { Loose and } \\
\text { soft }\end{array}$ & Loose & $\begin{array}{c}\text { Not plastic and } \\
\text { not sticky }\end{array}$ & $\mathrm{pg}$ \\
\hline & $\mathrm{AC}$ & $0,14-0,29$ & $\mathrm{BAE}$ & bsa, meg e fr & $\begin{array}{c}\text { Loose and } \\
\text { soft }\end{array}$ & Loose & $\begin{array}{c}\text { Not plastic and } \\
\text { not sticky }\end{array}$ & $\mathrm{pd}$ \\
\hline & $\mathrm{C} 1$ & $0,29-0,41$ & $\mathrm{BA}$ & bsa, gr e fr & Soft & $\begin{array}{c}\text { Very } \\
\text { Friable }\end{array}$ & $\begin{array}{c}\text { Not plastic and } \\
\text { not sticky }\end{array}$ & $\mathrm{pg}$ \\
\hline & $\mathrm{C} 2$ & $\begin{array}{l}0,41-0,56 / \\
(0,48-0,65)\end{array}$ & $\mathrm{BA}$ & bsa, gr e fr & $\begin{array}{c}\text { Soft and } \\
\text { slightly hard }\end{array}$ & $\begin{array}{c}\text { Very } \\
\text { Friable }\end{array}$ & $\begin{array}{c}\text { Not plastic and } \\
\text { not sticky }\end{array}$ & oa \\
\hline & $\mathrm{C} 3$ & $\begin{array}{c}0,56-0,81 / \\
(0,65-0,98)\end{array}$ & - & Massive & Hard & Firm & $\begin{array}{l}\text { Very plastic and } \\
\text { sticky }\end{array}$ & ic \\
\hline & $2 \mathrm{Cr}$ & $0,81-1,05^{+}$ & - & Massive & - & - & - & - \\
\hline & \multicolumn{8}{|c|}{ Inceptisols Ta Eutrophic vertissólico - CXve } \\
\hline \multirow{6}{*}{$\mathbf{P 2}$} & A & $0-0,14$ & $\mathrm{BE}$ & bsa, pem e mo & Hard & Firm & $\begin{array}{l}\text { Very plastic and } \\
\text { sticky }\end{array}$ & \\
\hline & $\mathrm{AB}$ & $0,14-0,29$ & $\mathrm{~B}$ & bsa e ba, me e mo & $\begin{array}{l}\text { Hard to very } \\
\text { hard }\end{array}$ & Firm & $\begin{array}{l}\text { Very plastic and } \\
\text { sticky }\end{array}$ & \\
\hline & Biv & $0,29-0,41$ & BAvE & ba, gr e mo & Very hard & $\begin{array}{l}\text { Very } \\
\text { Firm }\end{array}$ & $\begin{array}{l}\text { Very plastic and } \\
\text { sticky }\end{array}$ & \\
\hline & $\mathrm{BC}$ & $0,41-0,55$ & - & - & - & - & - & \\
\hline & $\mathrm{Cr}$ & $0,55-0,70^{+}$ & - & - & - & - & - & \\
\hline & \multicolumn{8}{|c|}{ Alfisols Haplic typical Eutrophic - SXe } \\
\hline \multirow{5}{*}{ P3 } & A & $0-0,12$ & BAE & gra e grs, me e fr & Soft & $\begin{array}{c}\text { Very } \\
\text { friable }\end{array}$ & $\begin{array}{c}\text { Not plastic and } \\
\text { not sticky }\end{array}$ & pg \\
\hline & $\mathrm{AE}$ & $0,12-0,33$ & $\mathrm{BA}$ & bsa, gr e fr & Slightly hard & $\begin{array}{c}\text { Very } \\
\text { friable }\end{array}$ & $\begin{array}{c}\text { Not plastic and } \\
\text { not sticky }\end{array}$ & pg \\
\hline & $\mathrm{E}$ & $0,33-0,51$ & $\mathrm{CC}$ & bsa, gr e fr & Slightly hard & Friable & $\begin{array}{c}\text { Not plastic and } \\
\text { not sticky }\end{array}$ & pa \\
\hline & $2 \mathrm{Bt}$ & $0,51-0,65 / 0,67$ & BAE & bsa, gr, fr e mo & $\begin{array}{l}\text { Hard to very } \\
\text { friable }\end{array}$ & $\begin{array}{l}\text { Crispy } \\
\text { and firm }\end{array}$ & $\begin{array}{l}\text { Slightly plastic } \\
\text { and sticky }\end{array}$ & ig \\
\hline & $2 \mathrm{Cr}$ & $0,65 / 0,67-0,79^{+}$ & - & - & - & - & - & - \\
\hline
\end{tabular}


continuation

Entisol Eutrophic Inceptisol - Rre

\begin{tabular}{|c|c|c|c|c|c|c|c|c|}
\hline \multirow{5}{*}{ P4 } & A & $0-0,18$ & BAm & bsa e grs, fr e me & Soft & $\begin{array}{l}\text { Very } \\
\text { friable }\end{array}$ & $\begin{array}{c}\text { Not plastic and } \\
\text { not sticky }\end{array}$ & $\mathrm{pc}$ \\
\hline & $\mathrm{C} 1$ & $0,18-0,42 / 0,53$ & BAm & bsa e grs, fr e me & Slightly hard & $\begin{array}{l}\text { Very } \\
\text { friable }\end{array}$ & $\begin{array}{l}\text { No plastic and } \\
\text { slightly sticky }\end{array}$ & oc \\
\hline & $\mathrm{C} 2$ & $0,42 / 0,53-0,72$ & $\mathrm{~B}$ & bsa e grs, fr e me & Slightly hard & $\begin{array}{l}\text { Very } \\
\text { friable }\end{array}$ & $\begin{array}{l}\text { No plastic and } \\
\text { slightly sticky }\end{array}$ & og \\
\hline & $2 \mathrm{Cr}$ & $0,72-1,00^{+}$ & BAmE & bsa e grs, fr e me & Slightly hard & $\begin{array}{l}\text { Very } \\
\text { friable }\end{array}$ & $\begin{array}{c}\text { No plastic and } \\
\text { not sticky }\end{array}$ & - \\
\hline & \multicolumn{8}{|c|}{ Inceptisols Ta Eutrophic vertissólico - CXve } \\
\hline \multirow{4}{*}{ P5 } & A & $0-0,06$ & $\mathrm{BME}$ & bsa, pem e mo & hard & Firm & Sticky & $\mathrm{pc}$ \\
\hline & Bi1 & $0,06-0,12$ & $\mathrm{CAE}$ & bsa, mgr e mogr & Very hard & $\begin{array}{l}\text { Firm to } \\
\text { very firm }\end{array}$ & $\begin{array}{l}\text { Very plastic and } \\
\text { sticky }\end{array}$ & $\mathrm{pd}$ \\
\hline & $\mathrm{Bi} 2$ & $\begin{array}{c}0,12-0,49 / \\
(0,43-0,56)\end{array}$ & VEA & bsa, fr e me & $\begin{array}{l}\text { Lasts to very } \\
\text { hard }\end{array}$ & Firm & $\begin{array}{l}\text { Very plastic and } \\
\text { sticky }\end{array}$ & $\mathrm{pg}$ \\
\hline & $\mathrm{BC}$ & $0,49-0,80^{+}$ & CAE & - & Very hard & Firm & $\begin{array}{c}\text { Plastic and } \\
\text { sticky }\end{array}$ & - \\
\hline
\end{tabular}

$\mathrm{BA}=$ Bruno Gray; BAE = Dark Gray Bruno; BE = Dark Bruno; B = Bruno; BAvE = Dark Reddish Bruno; CC = Light Gray; BAmE $=$ Bruno Yellowish Dark; BME = Very Dark Bruno; $\mathrm{CAE}=$ Dark Reddish Gray; VEA = Dark Gray Red; gra $=$ granular; grs $=$ simple grains; $\mathrm{me}=$ average; $\mathrm{fr}=$ weak; bsa = subangular blocks; mo = moderate; pem $=$ small to moderate; $\operatorname{mgr}=$ very large and $\mathrm{mogr}=$ moderate to large; $\mathrm{pg}=$ flat and gradual; $\mathrm{pd}=$ flat and diffuse; ao = wavy and abrupt; ic = irregular and clear; $\mathrm{pa}=$ flat and abrupt; $\mathrm{pc}=$ flat and clear; oc = wavy and clear; ig = irregular and gradual; og = wavy and gradual.

$\mathrm{P} 1$ presents horizons in the sequence A-AC-C1C2-C3 and $2 \mathrm{Cr}$, with a depth greater than $1.05 \mathrm{~m}$, a predominance of sand in the superficial horizons, and lithic contact to a depth greater than $0.50 \mathrm{~m}$; more than $5 \%$ of the mass volume of the $\mathrm{C} 1$ and $\mathrm{C} 2$ horizons with semi-weathered rock fragments. Based on morphological observations, C3 horizon has gravel and hardened, quartz texture (90\%), is rounded and rough, and is intermixed with whitish powdery material. This material covered the crystalline material and there were minimal changes in the superficial part, with evidence of clay at 2 :
1 , as shown by the presence of few cracks in the soil profile. The whitish powder between the quartz gravels is equal to horizon $\mathrm{C} 2$.

$\mathrm{P} 2$ presents $\mathrm{A}-\mathrm{AB}-\mathrm{Biv}-\mathrm{BC}$ and $\mathrm{Cr}$ horizons, with a subsurface diagnostic horizon B-incipient, depth less than $1.00 \mathrm{~m}$, and a decrease in the amount of clay in the soil profile, which is greater in the A-AB and Biv horizons, clayey texture, associated with high-activity clay (Ta), CTC higher than 17 cmolc $\mathrm{kg}^{-1}$ clay, and high base saturation $(\mathrm{V}>95 \%)$, (Tables 3 and 4). 
Table 3. Physical attributes of soils cultivated with sisal in the Bahian semi-arid.

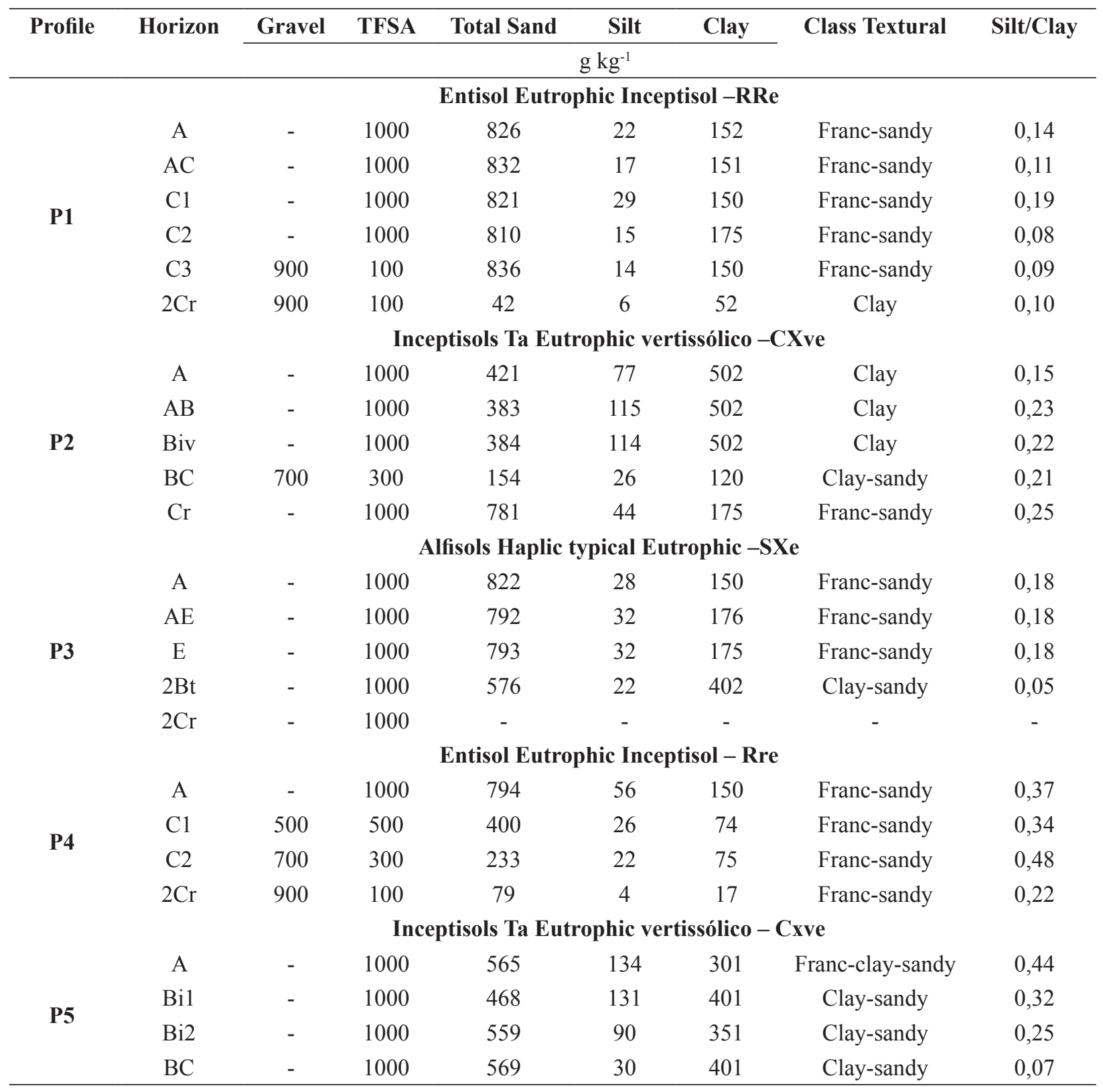


Table 4. Chemical attributes of the sisal-growing soils in the Brazil semi-arid region.

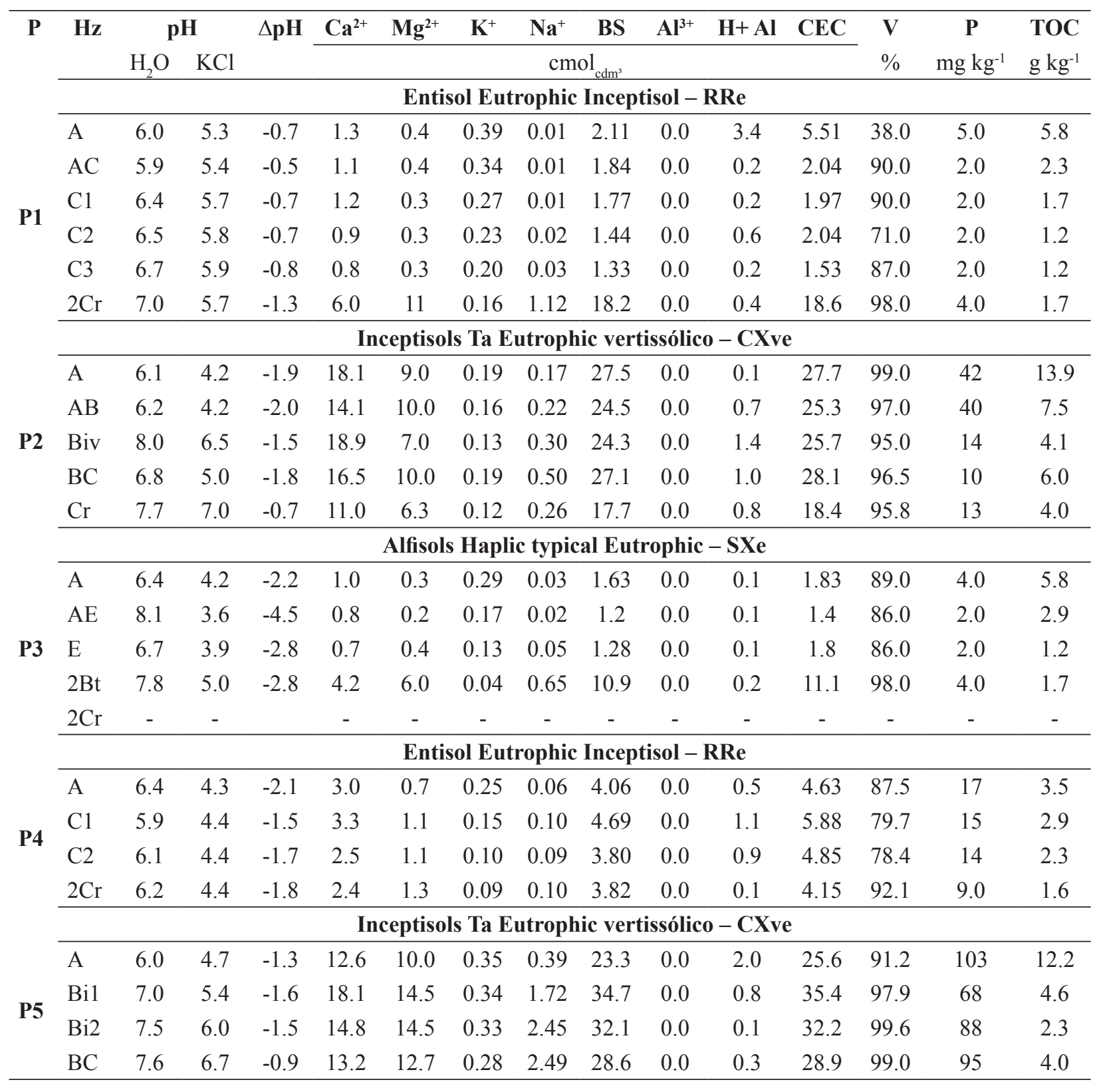

$\mathrm{P}=$ profile $\mathrm{Hz}=$ horizon; $\mathrm{SB}=$ sum of bases $\mathrm{CEC}=$ cation exchange capacity $\mathrm{V}=$ base saturation; $\mathrm{P}=$ available phosphorus.

The $\mathrm{P} 3$ presents horizons in the sequence A-AE$\mathrm{E}-2 \mathrm{Bt}$ and $2 \mathrm{Cr}$, and has a sandy to sandy-loam texture at horizons $\mathrm{A}-\mathrm{AE}$ and $\mathrm{E}$ and clay-sandy texture at $2 \mathrm{Bt}$, with sufficient clay formation at the subsurface horizon to result in an abrupt change in texture (Table 3 ).

P4 has similarities with $\mathrm{P} 1$, and has horizons in the sequence $\mathrm{A}-\mathrm{C} 1-\mathrm{C} 2$ and $2 \mathrm{Cr}$, with more than
$100 \mathrm{~cm}$ of depth and a sandy texture in all horizons (Table 3).

$\mathrm{P} 5$ presents horizons in the sequence A-Bi1-Bi2 and $\mathrm{BC}$, with a depth of approximately $80 \mathrm{~cm}$ and lower levels of clay in all horizons than P2, which also displayed the same classification (Table 3).

These profiles presented different morphological characteristics, although they are distributed along 
the Bahian semi-arid region under the same climatic conditions. Morphological variation in the profiles seems to be more closely related to geology and relief, which affects the movement of water in the soil profile and erosive processes of sedimentary material deposition.

Geological mapping of the region revealed the formation of crystalline rocks, gneiss, and migmatites in the Santa Luz complex (MELO et al., 2001). However, in the studied area, this material is largely covered by a thin layer of sandy sediments, which are present in nearby regions and have been described by Melo et al. (2001) as tertiary/ quaternary detrital coverings that discordantly cover the most diverse lithologies of the identified tectonostructural domains. These materials include quartz sand and rounded quartz gravel, often interspersed with fragments of rocks of newly altered crystalline material. Thus, soils are formed mostly by lithologic discontinuity or to a lesser extent, by the alteration of only one of these source materials. In this region, Brasil (1983) also described Planosols with and without lithologic discontinuity, demonstrating the presence of sedimentary coverings above the crystalline material during alteration.

As for the particle size distribution of the fine dry air (TFSA) of all horizons, the sand fraction was dominant, ranging from 383 to $836 \mathrm{~g} \mathrm{~kg}^{-1}$ (Table 3). The predominance of the sand fraction, mainly in the first three horizons, is characteristic of P1, P3, and P4 (OLIVEIRA et al., 2008; SANTOS et al., 2012). The higher amount of sand from the surface horizons, associated with the lithologic discontinuity between the surface horizons and $2 \mathrm{Bt}$, with a more permeable sandy layer covering the crystalline material in $\mathrm{P}$, favors the infiltration of water in the profile, forming an argillic horizon (B textural horizon) in situ and not only by the eluviation / illuviation process or preferential removal of clay from the surface horizons (MOTA et al., 2008; OLIVEIRA et al., 2008, 2009). This process is different from the formation of the Regolithic Neosols of the sisal-growing region, in which the sedimentary layer is more clayey and compact, which makes it difficult for water to percolate to lower layers. The distinction between these two soil classes has serious implications for soil management and crop productivity. Both soils are composed predominantly of the sand fraction and low levels of organic carbon confer a low cation exchange capacity to these soils, which favors strong nutrient leaching during rainy seasons (SANTOS et al., 2012). In addition, in the Planosols, the presence of the special B textural horizon (B) makes it difficult for water infiltration into the soil profile, favoring the removal of the richest nutrient surface horizon, exposing a more hardened subsurface horizon. With the exception of P5, the analyzed profiles had fractions greater than $2 \mathrm{~mm}$ in the soil mass of the subsurface horizons.

The silt fraction presented the lowest levels among all evaluated profiles in relation to the other fractions. The content varied from 4 to $115 \mathrm{~g} \mathrm{~kg}^{-1}$ and can be explained by the sandy composition of the sediments that covered the lens. These values are consistent with those found for developed soils of crystalline rocks in semi-arid regions (SANTOS et al., 2012; SOUZA et al., 2010).

The clay content varied from 50 to $502 \mathrm{~g} \mathrm{~kg}$. ${ }_{1}$, with the highest values observed in P2 and P5. The absence of expressive textural B in P2 and P5 is explained by the degree of weathering to which these soils are subjected. Because these were young soils, factors such as low precipitation and formation processes did not provoke noticeable changes in the deep textural differentiation (MOTA et al., 2008). According to Santos et al. (2012), clay content varying from 350 to $500 \mathrm{~g} \mathrm{~kg}^{-1}$ throughout the profile are not consistent with the class of Planosols and Regolithic Neosols, reinforcing the potential presence of a greater variety of soil classes in the sisal-growing region. 


\section{Chemical attributes}

Regarding $\mathrm{pH}$ (Table 4), the soils were acidic (5.4 to 6.5), neutral (6.6 to 7.3), and alkaline (7.4 to 8.3) (SANTOS et al., 2013). Considering that the areas are subjected to extractivist cultivation without application of correctives or fertilizers, this difference in $\mathrm{pH}$ is assumed to be due to slight variations in the composition of the source material or due to the position in the relief, which influences losses and the contributions of surface materials (SOUZA et al., 2010). The $\Delta \mathrm{pH}$ values were negative, indicating a predominance of negative charges on the surface of the colloids. All evaluated soils presented null or low levels of $\mathrm{Al}^{3+}$, with saturation percentages by bases between 71 and $99.6 \%$. High saturation by bases, which is associated with the absence of $\mathrm{Al}^{3+}$, helps to maintain $\mathrm{pH}$ values close to 6.5 (OLIVEIRA et al., 2009).

$\mathrm{Ca}^{2+}$ and $\mathrm{Mg}^{2+}$ were the predominant cations in the sorption complex, mainly in $\mathrm{P} 2$ and $\mathrm{P} 5$, with values of $18.9 \mathrm{cmolc} \mathrm{dm}^{-}{ }^{3}$ for $\mathrm{Ca}^{2+}$ and $14.5 \mathrm{cmolc} \mathrm{dm}^{-3}$ for $\mathrm{Mg}^{2+}$. These results contributed significantly to the high values obtained for base saturation $(\mathrm{V} \%)$, determining the eutrophic characteristic ( $\mathrm{V}>50 \%$ ) for almost all profiles evaluated, with the exception of P1, horizon A (Table 4). Notably, for soils that originated from the crystalline rocks, the content of the elements are higher in P2 and P5. Marques et al. (2007) reported similar results for Cambissolos Háplicos with characteristics comparable to those observed in the present study, and considered the areas to be optimal for agricultural use. Conversely, Souza et al. (2010) reported $\mathrm{Ca}^{2+}$ values between 2.8 and 0.5 cmolc dm- $^{-3}$ of soil in Haplic Cambisol, but with clay of low activity, and in some cases, the $\mathrm{Mg}^{2+}$ values were higher than those of $\mathrm{Ca}^{2+}$.

However, the saturation of these soils can lead to the incorrect interpretation of soil fertility and land use. High values of $\mathrm{V} \%$ are more indicative of the absence of $\mathrm{Al}^{3+}$ and $\mathrm{H}^{+}$or high levels of basic cations. For example, soils with $\mathrm{Ca}^{2+}$ and $\mathrm{Mg}^{2+}$ content lower than $2.0 \mathrm{cmolc} \mathrm{dm}^{3}$ are considered low, and those with values higher than 4 are considered high (RIBEIRO et al., 1999). Based on these values, cultivation at $\mathrm{P} 1$ and $\mathrm{P} 4$ should result in distinct productivity, since most crops require concentrations of $\mathrm{Ca}^{2+}$ and $\mathrm{Mg}^{2+}>2.0$ cmolc $\mathrm{dm}^{-3}$ to reach their maximum production potential (LOPES, 1998). P3 also has low levels of $\mathrm{Ca}^{2+}$ and $\mathrm{Mg}^{2+}$. Phosphorus is another element with divergent values between the Neosols. According to Ribeiro et al. (1999) P4 has a low concentration of $\mathrm{P}(<10$ $\mathrm{mg} \mathrm{dm}{ }^{-3}$ ), P2 and P5 profiles have mean to high concentrations (10.1-20 mg dm${ }^{-3}$; Table 4).

In the diagnostic horizons of the P2 and P5 profiles, the high clay activity resulted in these being classified as high clay activity horizons $(\mathrm{Ta})$. Clay activity is low (Tb) in P1, P3, and P4. High clay activity increases the retention of water and nutrients by the plants. It is responsible, in part, for the cohesion and adhesion of soil particles, is reflected by consistency, and is of great importance for soil management.

Sodium content was higher in the P5 profile and the sodium saturation varied from 2 to $9 \%$ (Table 4) and this profile was characterized as solodic (SANTOS et al., 2013).

The organic carbon content was low, even when the surface horizons were considered, which according to Embrapa (2006) would be classified as A weak. This was observed in P1, P3, and P4, which were characterized as sandy (OLIVEIRA et al., 2009). The highest values were observed in the surface horizons of P2 and P5. The content reached 13.9 and $12.2 \mathrm{~g} \mathrm{~kg}^{-1}$, respectively, in horizon A, and were classified as moderate A. Similar results were found by the Northeast Soil Exploration Survey, with a mean value of $12.3 \mathrm{~g} \mathrm{~kg}^{-1}$ reported for carbon in Cambisols (JACOMINE et al., 1971, 1972, 1973, $1975,1977)$. This is due to the higher amount of clay content observed in $\mathrm{P} 2$ and $\mathrm{P} 5$, which increases the adsorbtion of organic compounds to the surface of this mineral. The greater physical protection afforded by the structural conditions of the soils, and 
by the relief, determines the water regime of the soil and influences the distribution of litter on the soil surface (SALCEDO; SAMPAIO, 2008). In the P1, $\mathrm{P} 3$, and P4 profiles, besides the low contribution of vegetal material, the essentially sandy constitution of these soils also contributes to the low values of organic carbon (SANTOS et al., 2012; SOUZA et al., 2010).

In terms of fertility, Ribeiro et al. (1999) reported that P1 and P3 present low and medium levels of exchangeable $\mathrm{Ca}^{2+}, \mathrm{Mg}^{2+}$, and $\mathrm{P}$. These results are consistent with those presented by Silveira et al. (2006), who studied the distribution of phosphorus in seven different orders of soils in the Paraíba and Pernambuco semi-arid regions. Those authors concluded that Regolithic and Planosols Neosols contain lower values, supporting the observation that phosphorus is limiting in much of the northeastern semi-arid region.

Conversely, Ribeiro et al. (1999) noted that P4 holds the same classification as P1, with higher values of $\mathrm{Ca}^{2+}, \mathrm{Mg}^{2+}$, and $\mathrm{P}$, being classified as good and low, respectively. This may be related to the composition of the originating material that was covered by the sandy sediments.

Analysis of these parameters shows that the two studied soils (P1 and P3) have low agricultural potential, and that in the same region, soils with similar classifications (in this case P1 and P4) have different fertilities. The chemical attributes of the P2 and $\mathrm{P} 5$ profiles are also distinct, which may indicate that such soils originate from different rocks. This further reinforces the importance of studies that aim to increase knowledge on the different classes of soils existing in the semi-arid region, drawing the attention of producers and government agencies in relation to their use and management, in order to increase the productivity of the sisal crop and maintain the sustainability of the agricultural system and the ecosystem as a whole.

The concentrations of elements following the acid of sulfuric attack indicate that the $\mathrm{Ki}$ values are between 1.73 and 5.60 and the $\mathrm{Kr}$ values between 1.48 and 4.06, for all classes and profiles evaluated (Table 5). The high values of $\mathrm{Ki}$ and $\mathrm{Kr}$ suggest a low degree of pedogenesis, except for the Planosol, which presented the lowest values for the $\mathrm{AE}$ horizon. These low $\mathrm{Ki}$ and $\mathrm{Kr}$ values in the AE horizon of the Planosols is due to the nature of the sedimentary material. The higher value of aluminum oxide $\left(\mathrm{Al}_{2} \mathrm{O}_{3}\right)$ in relation to iron oxide $\left(\mathrm{Fe}_{2} \mathrm{O}_{3}\right)$ indicates the predominance of aluminum forms in all profiles studied. Pereira et al. (2010) reinforced the presence of illite in the clay fraction of soils, by the presence of dioctahedral micas to the detriment of trioctahedral micas. In the present study, this was observed in the $\mathrm{C} 2$ and Bi horizons of $\mathrm{P} 1$ and $\mathrm{P} 2$, respectively.

In soils for which there is discontinuity of source material, the difference in the total content of $\mathrm{SiO}_{2}$, $\mathrm{Al}_{2} \mathrm{O}_{3}, \mathrm{Fe}_{2} \mathrm{O}_{3}$, and $\mathrm{TiO}_{2}$ in sediments of the $\mathrm{P} 1$ profile and the $\mathrm{C} 3$ horizon, and in the $\mathrm{P} 3$ profile in the surface horizons (AE and $\mathrm{E}$ ) were much lower than those found for the content of these crystalline elements in profile $\mathrm{P} 1$ and horizon $2 \mathrm{Cr}$, and profile $\mathrm{P} 3$ in horizon $2 \mathrm{Bt}$, confirming the presence of lithologic discontinuity in these soils (BRASIL, 1983) obtained a profile of Planossol and reported lithologic discontinuity of material described in the sisal region. 
Table 5. Oxide content and $\mathrm{Ki}$ and $\mathrm{Kr}$ indexes determined by the sulfuric attack of selected horizons of the sisalgrowing soils in the semi-arid Bahia.

\begin{tabular}{ccccccccc}
\hline Profile & $\mathbf{H z}$ & $\mathbf{S i O}_{2}$ & $\mathbf{A l}_{2} \mathbf{O}_{\mathbf{3}}$ & $\mathbf{F e}_{2} \mathbf{O}_{\mathbf{3}}$ & $\mathbf{T i O}_{2}$ & $\mathbf{M n O}$ & $\mathbf{K i}$ & $\mathbf{K r}$ \\
\hline \multirow{3}{*}{$\mathrm{P} 1$} & & & \multicolumn{2}{c}{$\mathbf{\%}$} & & & & \\
\cline { 2 - 9 } & $\mathrm{C} 3$ & 3.90 & 1.84 & 0.39 & 0.11 & 0.01 & 3.60 & 3.17 \\
& $2 \mathrm{Cr}$ & 23.1 & 12.6 & 3.12 & 0.50 & 0.01 & 3.12 & 2.69 \\
\hline \multirow{2}{*}{$\mathrm{P} 2$} & $\mathrm{Bi}$ & 19.3 & 8.00 & 6.69 & 0.86 & 0.09 & 4.10 & 2.67 \\
& $\mathrm{BC}$ & 16.4 & 6.78 & 5.35 & 5.52 & 0.04 & 4.11 & 2.73 \\
\hline \multirow{3}{*}{$\mathrm{P} 3$} & $\mathrm{AE}$ & 2.70 & 2.65 & 0.7 & 0.15 & 0.01 & 1.73 & 1.48 \\
& $\mathrm{E}$ & 2.80 & 1.84 & 0.58 & 0.13 & 0.01 & 2.59 & 2.15 \\
& $2 \mathrm{Bt}$ & 12.9 & 8.21 & 1.94 & 0.38 & 0.01 & 2.67 & 2.32 \\
\hline \multirow{2}{*}{$\mathrm{P} 4$} & $\mathrm{C} 1$ & 7.00 & 3.47 & 0.93 & 2.04 & 0.01 & 3.43 & 2.93 \\
& $\mathrm{C} 2$ & 8.30 & 2.96 & 0.81 & 2.11 & 0.01 & 4.77 & 4.06 \\
\hline \multirow{3}{*}{$\mathrm{P} 5$} & $\mathrm{Bi} 1$ & 16.5 & 5.51 & 4.52 & 6.03 & 0.06 & 5.09 & 3.34 \\
& $\mathrm{Bi} 2$ & 14.8 & 4.49 & 3.71 & 5.27 & 0.05 & 5.60 & 3.67 \\
& $\mathrm{BC}$ & 13.9 & 5.81 & 3.67 & 6.16 & 0.05 & 4.07 & 2.90 \\
\hline
\end{tabular}

$\mathrm{Hz}=$ horizon; $\mathrm{Ki}=\left(\mathrm{SiO}_{2} / \mathrm{Al}_{2} \mathrm{O}_{3}\right) \times 1.7 ; \mathrm{Kr}=\left(\mathrm{SiO}_{2} \times 1.7\right) /\left(\mathrm{Al}_{2} \mathrm{O}_{3}+\left(0.64 \times \mathrm{Fe}_{2} \mathrm{O}_{3}\right)\right)$.

The mineralogy of the clay fraction was more complex and was composed of a variety of minerals, with a predominance of kaolinite and bayerite. In addition, goethite and illite were found in most of the studied profiles, both in the sediment, in the $\mathrm{P} 1$ profile, and in the $\mathrm{C} 2$ horizon, as well as in the crystalline profile, and $\mathrm{P} 1, \mathrm{P} 2, \mathrm{P} 3$, and $\mathrm{P} 5$ profiles in the $\mathrm{Cr}, \mathrm{Bi}, 2 \mathrm{Cr}$, and $\mathrm{Bi}$ horizons (Figure 1A, 1B, $1 \mathrm{C}, 1 \mathrm{D}$, and $1 \mathrm{E})$.

The presence of minerals such as illite is of great importance for soils of semiarid regions, which are sandy and have a low capacity to retain cations. Illite combined with easily weathered minerals, especially in the finer fractions, favors the sorption of ions, which become an important source of mineral reserve in the soil (COSTA; BIGHAM, 2009; SANTOS et al., 2012). This may explain the classification of the eutrophic characteristics in the large group of all profiles studied.

It is notable that bayerite is present in all clay fraction, except for P2Bi. Bayerite is an aluminum hydroxide $\left(\beta-\mathrm{Al}[\mathrm{OH}]^{3}\right)$ with a fundamental structure similar to that of gibbsite and nordstrandite (KÄMPF et al., 2009). Those authors stated that, in bayerite, the packaging is denser, as $\mathrm{OH}$ - ions of one slide are located in subsequent slides; moreover, it is rarely found in the environment and is occasionally observed in calcareous materials.

Table 3 shows the low content of the clay fraction in most of the P1 and P3 horizons of the studied soils. The mineralogical characterization of the clay fraction revealed monosialitization in the profiles formed by sediments, indicated by the kaolinite constitution, and bissialitization in the P2 and P5, profiles formed by the incipient intemperization of the crystalline rocks, indicated by the constitution of the illite. The presence of these different formation processes supports the existence of soil classes distinct from those present in the exploratory surveys of soils of the sisal-growing region as reported in the RadamBrasil project (BRASIL, 1983), CPRM (MELO et al., 2001), and Embrapa solos, Recife unit (EMBRAPA, 2006). 
Figure 1. X-ray diffractograms of the clay fraction of the profiles $\mathrm{P} 1-\mathrm{C} 2$ and $\mathrm{Cr}(\mathrm{A}), \mathrm{P} 2-\mathrm{Bi}(\mathrm{B}), \mathrm{P} 3-2 \mathrm{Cr}(\mathrm{C}), \mathrm{P} 4-\mathrm{C} 1$ (D), and P5-B1 (E). Ct = Kaolinite; Gt = Goethite; It = Illite; Ba = Bayerite; Qz- Quartz; Fd-K -Feldspar K; FIFayalite; Pg- Plagioclase; Gs- Glossular.

(A)

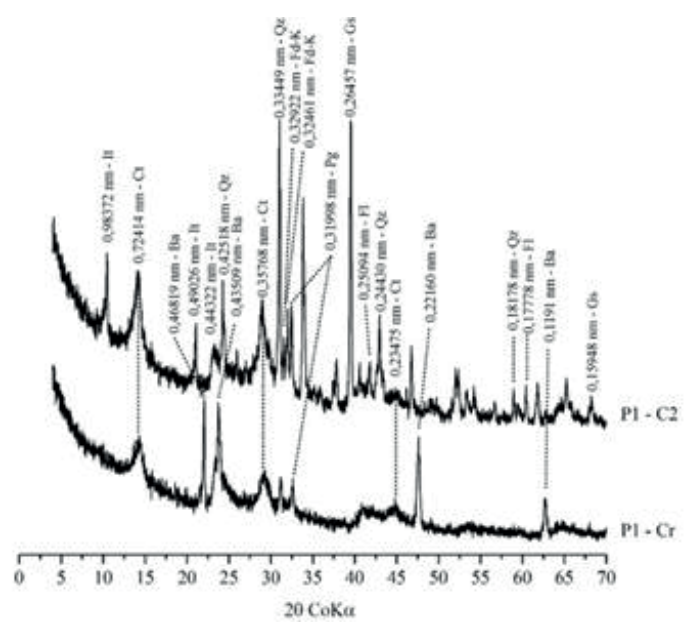

(C)

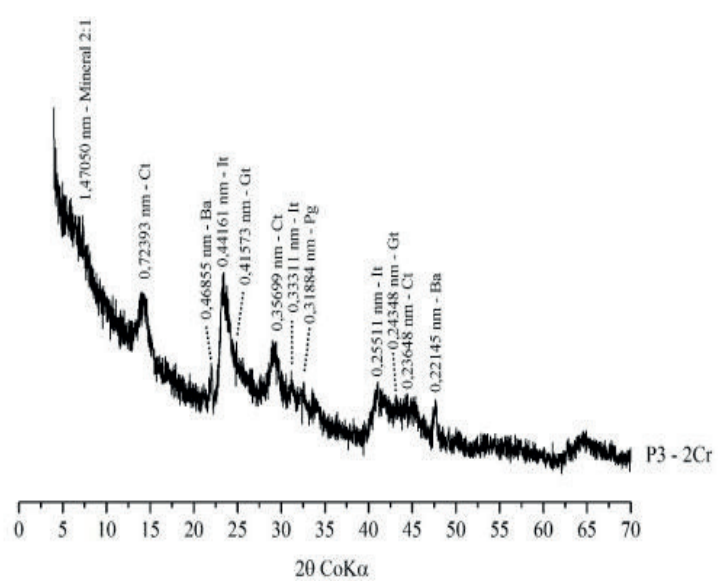

(B)

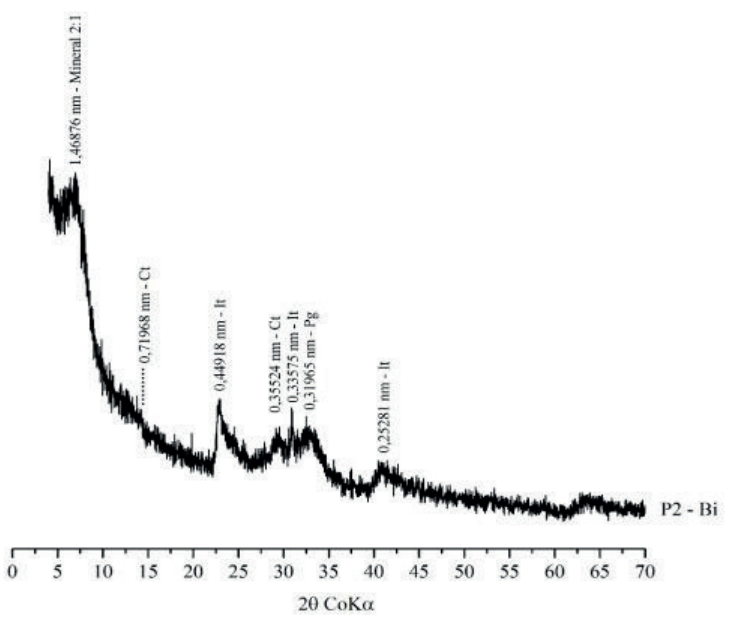

(D)

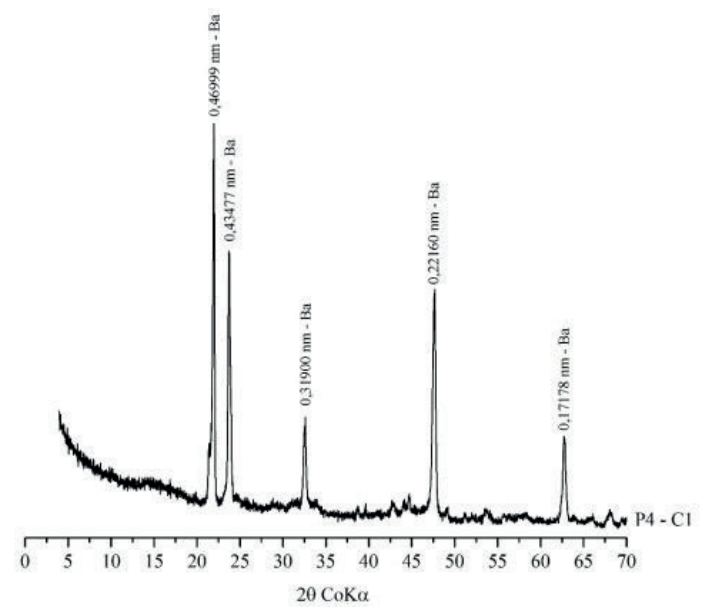

(E)
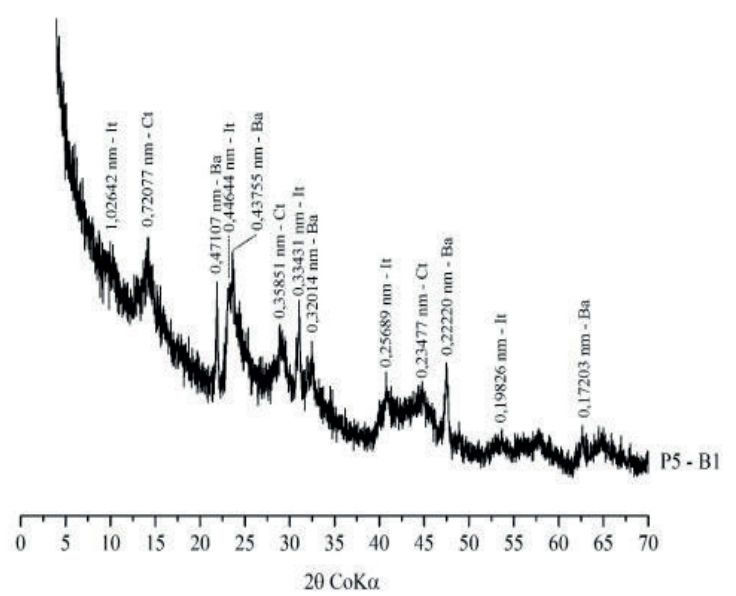


\section{Soil classification}

According to the Brazilian Soil Classification System, P1 and P4 belong to the Neossolos (Entisols) class, (SANTOS et al., 2013). At the suborder level, it was classified as a Neolithic Regolithic, that is, soil with little evolution and without any type of diagnostic B horizon, with A horizon over-lying $\mathrm{C}$ or $\mathrm{Cr}$, and lytic contact to a depth greater than $50 \mathrm{~cm}$. In the large group, P1 was classified as Eutrophic, which represents soils with saturation by bases greater or equal to $50 \%$ (Table 4 ). At the subgroup level, the profile was identified as a leptic, as it presented lytic contact between 50 and $100 \mathrm{~cm}$ from the soil surface (SANTOS et al., 2013).

The $\mathrm{P} 2$ and $\mathrm{P} 5$ profiles were identified at the first categorical level as belonging to the Cambissolos (Inceptsols) class, from the Haplic suborder. For the large group and subgroup, the profile was classified as Vertisolic Eutrophic Ta.

P3 was classified as belonging to the Planossolos (Alfisols) class and the Haplogic suborder. At the large group and subgroup levels, it was classified as typical Eutrophic.

\section{Conclusions}

In contrast to that found in exploratory surveys of soils for the sisal-growing region, in the $\mathrm{P} 2$ and $\mathrm{P} 5$ profiles, the soils presented high values of calcium and magnesium and high clay activity, indicating that these soils are highly fertile.

The mineralogy of the clay fraction was more complex, and was composed of a variety of minerals, with a predominance of kaolinite and bayerite. Besides these minerals, goethite and illite were also found in most of the studied profiles, in the sediment, in the $\mathrm{P} 1$ profile $\mathrm{C} 2$ horizon, and in the crystalline profile, profiles P1, P2, P3, and P5, and horizons $\mathrm{Cr}, \mathrm{Bi}, 2 \mathrm{Cr}$, and $\mathrm{Bi}$, respectively.

Soils were classified, up to the fourth categorical level, as: Entisol Eutrophic Inceptisol(RRe); Alfisols
Haplic typical Eutrophic (SXe), and Inceptisols Ta Eutrophic vertissólico (CXve).

\section{References}

BRASIL. Ministério das Minas e Energia. SecretáriaGeral. Projeto RadamBrasil. Rio de Janeiro: Folhas SC. 24/25 Aracajú/Recife; geologia, geomorfologia, pedologia, vegetação e uso potencial da terra, 1983.

BRANDÃO. L. G. N.; PEREIRA, L. G. R.; AZEVÊDO, J. A. J.; SANTOS; R. D.; ARAÚJO, G. G. L.; DÓREA, J. R. R.; NEVES, A. L. A. Efeito de aditivos na composição bromatológica e qualidade de silagens de coproduto do desfibramento do sisal. Semina: Ciências Agrárias, Londrina, v. 34, n. 6, p. 2991-3000, 2013.

CHEN, P. Y. Table of key-lines in X-ray power diffraction patterns of minerals in clay and associated rocks. Indiana: Bloomington, 1977. 65 p. (Geological survey occasional paper the Department of Natural Resources, 21).

COSTA, A. C. S.; BIGHAM, J. M. Óxidos de ferro. In: MELO, V. F.; ALLEONI, L. R. F. (Ed.). Química e mineralogia do solo parte I. Viçosa, MG: SBCS, 2009. p. 506-520.

DONAGEMA, G. K.; CAMPOS, D. V. B.; CALDERANO, S. B.; TEIXEIRA, W. G.; VIANA, J. H. M. Manual de métodos de análises de solos. 2. ed. Rio de Janeiro: EMBRAPA, 2011. 230 p.

EMPRESA BRASILEIRA DE PESQUISA AGROPECUÁRIA - EMBRAPA. Solos do Nordeste. Recife: EMBRAPA Solos, 2006. Disponível em: http:// www.uep.cnps.embrapa.br/solos/>. Acesso em: 6 maio 2017.

INSTITUTO BRASILEIRO DE GEOGRAFIA E ESTATÍSTICA - IBGE. Produção da Pecuária municipal. Rio de Janeiro: IBGE, 2013. Disponível em: $<$ http://www. ibge.gov.br/<3ftp://ftp.ibge.gov.br/Producao Pecuaria/ Producao_da_Pecuaria_Municipal/2013/ppm2013.pdf $>$. Acesso em: 8 jun. 2016.

JACOMINE, P. T. K.; ALMEIDA, J. C.; MEDEIROS, L. A. R. Levantamento exploratório-reconhecimento de solos do Estado do Ceará. Recife: Ministério da Agricultura/ Superintendência do Desenvolvimento do Nordeste, 1973. v. 1, 301 p. (Boletim técnico, 28; Série Pedologia, 16).

JACOMINE, P. T. K.; PESSOA, S. C. P.; SILVEIRA, C. O. Levantamento exploratório-reconhecimento de solos do Estado de Alagoas. Recife: Brasileira de Pesquisa Agropecuária/Superintendência do Desenvolvimento do 
Nordeste, 1975. 526 p. (Boletim técnico; Série Recursos de Solos, 5).

JACOMINE, P.T. K.; RIBEIRO, M. R.; MONTENEGRO, J. O. Levantamento exploratório-reconhecimento de solos do Estado da Paraíba. Rio de Janeiro: Ministério da Agricultura/ Superintendência do Desenvolvimento do Nordeste, 1972. 650 p. (Boletim técnico, 15; Série Pedologia, 8).

JACOMINE, P. T. K.; SILVA, F. B. R.; FORMIGA, R. A.; ALMEIDA, J. C.; BELTRÃO, V. C.; PESSOA, S. C. P.; FERREIRA, R. C. Levantamento exploratórioreconhecimento de solos do Estado do Rio Grande do Norte. Recife: DNPEA/DPP, 1971. v. 9, 526 p. (Boletim técnico, 21-SUDENE/DRN. Série Pedologia).

JACOMINE, P. T. K.; SILVA, F. B. R.; MONTENEGRO, J. O.; FORMIGA, R. A.; BURGOS, N.; MELO FILHO, H. F. R. Levantamento exploratório-reconhecimento de solos da margem direita do rio São Francisco, Estado da Bahia. Recife: Brasileira de Pesquisa Agropecuária/ Superintendência do Desenvolvimento do Nordeste, 1977. v. 1, 736 p. (Boletim técnico, 52; Série Recursos de Solos, 10).

KÄMPF, N.; CURI, N.; MARQUES, J. J. Óxidos de alumínio, silício, manganês e titânio. In: MELO, V. F.; ALLEONI, L. R. F. Química e mineralogia do solo, parte I. Viçosa, MG: SBCS, 2009. p. 574-599.

LOPES, A. S. Manual internacional de fertilidade do solo. 2. ed. Piracicaba: POTAFOS, 1998, 177 p.

MARQUES, F. A.; RIBEIRO, M. R.; BITTAR, S. M. B.; LIMA NETO, J. A.; LIMA, J. F. W. F. Caracterização e classificação de Cambissolos do Arquipélago de Fernando de Noronha, Pernambuco. Revista Brasileira de Ciência do Solo, Viçosa, MG, v. 31, n. 5, p. 10231904, 2007.

MELO, R. C.; LOUREIRO, H. S. C.; PEREIRA, L. H. M. Programa levantamentos geológicos básicos do Brasil. - PLGB. Serrinha - Folha SC.24-Y-D. Estado da Bahia. Escala 1:250.000. In: MELO, R. C.; PEREIRA, L. H. M. Programa levantamentos geológicos básicos do Brasil. Brasília: CPRM/DIEDIG/DEPAT, 2001. p. 10-32.

MOTA, J. C. A.; ASSIS JÚNIOR, R. N.; AMARO FILHO, J.; LIBARDI, P. L. Algumas propriedades físicas e hídricas de três solos na Chapada do Apodi, RN, cultivados com melão. Revista Brasileira de Ciência do Solo, Viçosa, MG, v. 32, n. 1, p. 49-58, 2008.

OLIVEIRA, L. B.; FONTES, M. P. F.; RIBEIRO, M. R.; KER, J. C. Micromorfologia e gênese de Luvissolos e Planossolos desenvolvidos de rochas metamórficas no semiárido. Revista Brasileira de Ciência do Solo, Viçosa, MG, v. 32, n. 6, p. 2407-2423, 2008.
Morfologia e classificação de Luvissolos e Planossolos desenvolvidos de rochas metamórficas no semiárido do nordeste brasileiro. Revista Brasileira de Ciência do Solo, Viçosa, MG, v. 33, n. 5, p. 1333-1345, 2009.

PARAHYBA, R. B. V.; SANTOS, M. C.; ROLIM NETO, F. C.; JACOMINE, P. K. T. Pedogênese de Planossolos em topossequência do Agreste pernambucano. Revista Brasileira de Ciência do Solo, Viçosa, MG, v. 34, n. 6, p. 1991-2000, 2010.

PEREIRA, T. T. C.; KER, J. C.; SCHAEFER, E. G. R.; BARROS, N. F.; NEVES, J. C. L.; ALMEIDA, C. C. Gênese de Latossolos e Cambissolos desenvolvidos de rochas pelíticas do Grupo Bambuí - Minas Gerais. Revista Brasileira de Ciência do Solo, Viçosa, MG, v. 3, n. 4, p. 1283-1295, 2010.

RIBEIRO, A. C.; GUIMARÃES, P. T. G.; ALVAREZ, V. V. H. Recomendação para o uso de corretivos $e$ fertilizantes em Minas Gerais. Viçosa, MG: Comissão de Fertilidade do Solo do Estado de Minas Gerais, 1999. $359 \mathrm{p}$.

SALCEDO, I. H.; SAMPAIO, V. S. B. Matéria orgânica do solo no Bioma Caatinga. In: SANTOS, G. A.; SILVA, L. S.; CANELLAS, L. P.; CAMARGO, F. A. O. Fundamentos da matéria orgânica do solo, ecossistemas tropicais e subtropicais. Porto Alegre: Gênesis, 2008. p. 419-441.

SANTOS, H. G.; JACOMINE, P. K. T.; ANJOS, L. H. C.; OLIVEIRA, V. A.; LUMBRERAS, J. F.; COELHO, M. R.; ALMEIDA, J. A.; CUNHA, T. J. F.; OLIVEIRA, J. B. Centro nacional de pesquisa de solos. Sistema brasileiro de classificação de solos. Brasília: EMBRAPA, 2013. $353 \mathrm{p}$.

SANTOS, J. C. B.; SOUZA JÚNIOR, V. S.; CORRÊA, M. M.; RIBEIRO, M. R.; ALMEIDA, M. C.; BORGES, L. E. P. Caracterização de Neossolos Regolíticos da região semiárida do Estado de Pernambuco. Revista Brasileira de Ciência do Solo, Viçosa, MG, v. 36, n. 3, p. 683-695, 2012.

SANTOS, R. D.; LEMOS, R. C.; SANTOS, H. G.; KER, J. C.; ANJOS, L. H. C. (Ed.). Manual de descrição e coleta de solo no campo. Viçosa, MG: Sociedade Brasileira de Ciência do Solo, 2015. 100 p.

SILVEIRA, M. M. L.; ARAÚJO, M. S. B.; SAMPAIO, E. V. S. B. Distribuição de fósforo em diferentes ordens de solo do semi-árido da Paraíba e de Pernambuco. Revista Brasileira de Ciência do Solo, Viçosa, MG, v. 30, n. 2, p. 281-291, 2006.

SOIL SURVEY STAFF. Keys to soil taxonomy. $12^{\text {th }}$ ed. USDA NRCS, Washington, DC, 2014. 
SOUZA, R. V. C. C.; RIBEIRO, M. R.; SOUZA JÚNIOR， SUPERINTENDÊNCIADE ESTUDOS ECONÔMICOS V. S.; CORREAA, M. M.; ALMEIDA, M. C.; CAMPOS, E SOCIAIS DA BAHIA - SEI. Sistemas de dados M. C. C.; RIBEIRO FILHO, M. R.; SHULZE, S. B. B. ～estatístico. Salvador: SEI, 2016. Disponível em: <http:// Caracterização de solos em um topoclimossequência no maciço de Triunfo - Sertão de Pernambuco. Revista Brasileira de Ciência do Solo, Viçosa, MG, v. 34, n. 4, p. www.sei.ba.gov.br/side/frame_tabela.wsp?tm volta $=\mathrm{sg} 46 \& \mathrm{tmp}$. tabela=t106>. Acesso em: 22 abr. 1259-1270, 2010. 